ISSN 0258-7122 (Print), 2408-8293 (Online)

Bangladesh J. Agril. Res. 41(1): 115-125, March 2016

\title{
ASSESSMENT OF MICROBIAL QUALITY OF WATER IN POPULAR RESTAURANTS IN SYLHET CITY OF BANGLADESH
}

\author{
AYESHA SARKER ${ }^{1}$, SHARMista DASH ${ }^{2}$, MD. MOZAMMEL HOQUE ${ }^{3}$ \\ SULTAN AHMED ${ }^{4}$, AND MD. RAYHAN SHAHEB ${ }^{5}$
}

\begin{abstract}
Microbial contaminations of drinking water constitute a major burden on human health. Interventions to improve the quality of drinking-water provide significant benefits to health. An assessment of microbial quality of water in the samples obtained from different popular restaurants of Sylhet City Corporation, Bangladesh were analyzed in the laboratory. Our aims were to find out the microbial properties of water, to analyze the potable water qualities of the restaurants and also to compare it with different standards to assess the health risk of people. The microbial tests viz. MPN, TVC and total coliform test were studied. Results revealed that all the water samples were fecal contaminated and had a great chance of contamination by other pathogenic bacteria. Results indicated that most of the samples were significantly positive to MPN test and TVC bacteria were highly significant. The risk score for coliform bacteria also remarked high risk for human health according to WHO standards and were not suitable as potable water. Our recommendations are therefore, water supply authority including restaurant owners should take necessary steps for the maintenance of microbial quality of water and microbial assessments should be done very often to leading a hygienic water distribution environment of the city.
\end{abstract}

Keywords: Microbial properties, water quality, fecal coliform, MPN index, human health.

\section{Introduction}

The quality of drinking water is closely associated with human health, and providing of drinking water is one of the important public health priorities. The impact of water on health derives principally from the consumption of water, containing pathogenic organisms or toxic chemicals. In the developing countries, consumption of contaminated water is responsible for $80 \%$ of all diseases and hence, causes one third of deaths (UNCED, 1992). Bangladesh is not an exception in this regard and the drinking water quality is at high risk and problems are even more acute in the urban areas. Sylhet is a north-eastern

\footnotetext{
${ }^{1-2}$ Assistant Professor, Department of Food Engineering and Tea Technology, ${ }^{3}$ Professor, Dept. Of Food Engineering and Tea Technology, Shahjalal University of Science and Technology (SUST), Sylhet-3114, ${ }^{4}$ Associat Professor, Dept. Of Microbiology and Hygiene, Sylhet Agricultural University, Sylhet, ${ }^{5}$ Senior Scientific Officer, On-Farm Research Division, Bangladesh Agricultural Research Institute (BARI), Sylhet, Bangladesh.
} 
divisional city of Bangladesh, rich in natural resources that attract tourists and business entrepreneurs. According to Sylhet City Corporation, the city has 331 registered/licensed restaurants. However, many unregistered restaurants also exist. Only $15 \%$ of the restaurants maintain sanitary facilities and the rest $85 \%$ remains in unhygienic conditions that are unsafe for public health (Ahmed and Rahman, 2000). Alam et al. (2006) reported that the drinking water of each surveyed restaurant in the supply water of Sylhet City Corporation was contaminated with fecal coliforms and from which $25 \%$ restaurants had unsafe levels of iron. Health risk score for coliform bacteria was at high risk and about half of the population (55\%) comes under very high risk zone in the city. According to WHO/UNICEF Joint Monitoring Programme for Water Supply and Sanitation (2000), approximately $20-40 \%$ of urban water systems in the developing countries do not disinfect their water supplies. Contaminated water, poor sanitation and improper hygiene practice leads to water borne diseases. As a consequence, 34 million deaths a year occur throughout the world, which are mostly children (UNICEF, 2008).

According to a systematic review on microbial drinking water quality, even the improved sources including piped water were observed to be contaminated with E. coli or TTC (Bain et al., 2014b). Thus, microbial contamination is widespread and affects all water sources (Bain et al., 2014a). Piped water supply is available to about $60 \%$ of the Dhaka city population, but the city dwellers often find that the water is contaminated and needs boiling at home for drinking because of leaks in pipeline, imperfect water taps and misuse (Nazz, 2008). Hence, 89\% samples were not up to the standard level as drinking water and there was the presence of total viable bacteria, total coliform, total faecal coliform etc. in the piped water in Dhaka city (Zakia et al., 2001). Also, in some locations in Chittagong, pathogenic organisms present in water exceed the permissible limit (Zuthi et al., 2009). Similarly, Nasrin et al. (2005) reported that drinking water quality in the distribution network in Khulna City Corporation at some locations did not meet the potable water quality standard. In Bangladesh, about $80 \%$ of all diseases are linked with contaminated water and $28 \%$ of children's death is attributed to waterborne diseases caused by pathogenic microorganisms (Aziz et al., 1990).

Apart from Bangladesh, several researchers in different countries around the world also observed that various disease-causing agents or pathogens viz. faecal coliform bacteria or toxic chemicals result in water contamination. As a consequence, consumption of water leads to several health problems once the water travels through a distribution system (Lahlou, 2002; Howard, 2002; ObiriDanso et al., 2003; Dodoo et al., 2006). Guidelines for Drinking-Water Quality recommend that faecal indicator bacteria (FIB), preferably E. coli or alternatively thermotolerant coliform (TTC), should not be detectable in any $100 \mathrm{ml}$ drinking 
water sample (WHO, 2011). The 2010 global burden of disease estimates (Lim et al., 2012) assumed that improved sources present no risk to consumer. Unclean and unsafe water, poor sanitary and hygienic facilities in restaurants of the city possess a potential source of diseases and risk to human health. Nevertheless, very few studies were observed in these regards in Sylhet City Corporation. In view of this, the present investigation aimed at studying water quality of selected restaurants of Sylhet City with the objectives to find out the microbiological properties of water, to analyze the potable water qualities of popular restaurants and also to compare it with different standards to assess the health risk of people.

\section{Materials and Method}

\section{Study area and experimental design}

The study was carried out at the Department of Food Engineering and Tea technology laboratory, Shahjalal University of Science and Technology and Microbiology and Hygiene Laboratory, Sylhet Agricultural University, Sylhet, Bangladesh during the year 2011. Water samples were collected from various popular restaurants situated in different parts of Sylhet City Corporation (SCC), Bangladesh. It was observed that most of the restaurants used water for drinking and cooking purpose supplied by SCC. Completely randomized design was followed with three replications.

\section{Media used and working steps}

Growth media viz. Lactose Broth (LB), Plate Count Agar (PCA) or Nutrient Agar (NA) and Eosine Methylene Blue (EMB) Agar were used for microbial study. The whole experiment was conducted in the following four steps. Step-I: collection of supply water samples from different restaurants of Sylhet City Corporation (SCC), step-II: tests of the samples for microbial properties in the laboratories, step-III: comparison with different standard guidelines for drinking water and step-IV: assessment of water quality of the restaurant in SCC.

\section{Collection of sample and their preservation}

The water samples were collected from 20 (twenty) various popular restaurants in different wards of SCC which are shown in Table 1. Two liters of sample were collected from each restaurant in plastic containers. The containers were cleaned with cleaning solution prior to sample collection. Before taking the samples from the tap, it was allowed to flow for a while and the containers were rinsed at least three times by filling it to one fourth of its capacity with water to be sampled, properly shaked and then emptied. The containers were air tighten with stopper and wrapped by tape to restrict contact of air with water samples. All possible efforts were made to minimize the time lag between collection and analysis so as to avoid significant change in water quality. All the samples were then 
transported to the laboratory in an isolated foam box with ice to maintain temperatures ranging from $4-6^{\circ} \mathrm{C}$. After that samples were stored in the laboratory in $4^{\circ} \mathrm{C}$ temperature.

Table 1. List of the sampling restaurants

\begin{tabular}{cll}
\hline Code No. & \multicolumn{1}{c}{ Selected restaurants } & \multicolumn{1}{c}{ Address } \\
\hline S1001 & Gram Bangla Restaurants & JollarPar, Sylhet \\
S1002 & Pritiraj Restaurant & Zindabazar, Sylhet \\
S1003 & Alpine Restaurants & Chowhatta, Sylhet \\
S1004 & Ashiana Restaurants & Chowhatta, Sylhet \\
S1005 & Panchkhana Restaurants & Amberkhana, Sylhet \\
S1006 & Safran Restaurants & Shibgonj, Sylhet \\
S1007 & Rongdhonu Restaurants & Amberkhana, Sylhet \\
S1008 & Akash Restaurants & Modina Market, Sylhet \\
S1009 & Fatema Restaurants & Lamabazar, Sylhet \\
S1010 & Istikutum Restaurants & Amberkhana, Sylhet \\
S1011 & Rosuighar Restaurants & Pathantula, Sylhet \\
S1012 & Nobanno Restaurants & Taltola, Sylhet \\
S1013 & Fakrudddin Restaurants \& Biriany House & Barutkhana, Sylhet \\
S1014 & Satkania Restaurants & Dorgha Gate, Sylhet \\
S1015 & Choruivati Restaurants & SUST gate, Sylhet \\
S1016 & City Restaurants & Amberkhana, Sylhet \\
S1017 & Panchbhai Restaurants & JollarPar, Sylhet \\
S1018 & Dhansiri Restaurants & Subidbazar, Sylhet \\
S1019 & Habib Restaurants & Amberkhana, Sylhet \\
S1020 & Al-Kawsar Restaurants & Zindabazar, Sylhet \\
\hline & &
\end{tabular}

\section{Microbial properties tests}

Tests for indicator bacteria were done for the assessment of microbial properties of water samples. Indirect evidence of presence of pathogens was also confirmed by coliform test. Most probable number (MPN), confirmed test for coliform and total viable count or standard plate count were studied for microbial properties analysis.

\section{Most Probable Number (MPN) or Presumptive test for Coliform}

MPN provides an estimate of the number of living organisms in a sample which are capable of multiplying in the sample. The test is used when the number of microorganisms is very few $\left(<1 \mathrm{ml}^{-1}\right)$ in the sample. This method can be conducted by different techniques and the three tubes techniques were used here 
for determining MPN of the sample (Methods adapted from Alam et. al. 2006). However, multiple samples of water being tested were added to a lactose broth in sterile tubes and inoculated at $35^{\circ} \mathrm{C}$ temperature for 24 hours. Nine tubes were used for each sample. Three tubes of single strength lactose broth were inoculated with $0.1 \mathrm{ml}$ sample per tube and another three tubes of single strength lactose broth were inoculated with $1 \mathrm{ml}$ sample per tube. Ten $\mathrm{ml}$ of samples were also inoculated in three tubes of double strength lactose broth. As coliform bacteria were grown, they produced acid and gas, changing the broth colour and producing bubbles, which were captured in a small inverted tube. The number of tubes showing a positive result were counted and compared with standard tables. Statistical estimates of the MPN of bacteria were then made with the results reported as MPN per 100ml.

\section{Confirm test for Coliform}

This test was meant for differentiating the coliforms with that of non-coliforms as well as Gram-negative with Gram-positive bacteria. The Eosine Methyline Blue (EMB) agar plates were inoculated from previous tubes producing gas and incubated at $30 \pm 1{ }^{\circ} \mathrm{C}$ for 12 hours. E. coli colonies grown on this medium were observed as small with metallic sheen, whereas E. aerogenes colonies were usually large and lack the sheen.

\section{Total Viable Count (TVC) or Standard Plate Count (SPC)}

Total Viable Count gives a quantitative idea about the presence of micro organisms such as bacteria, yeast and mould in a sample. TVC was determined by multiplying colony numbers with reciprocal dilution factor and reported as the number of colony forming units per gram $\left(\mathrm{cfug}^{-1}\right) \mathrm{or} \mathrm{ml}^{-1}$ and the results per dilution counted were recorded. It was done to enumerate total viable population (eg. bacterial population) and not to detect either coliform or other pathogenic forms present therein. After inoculation and incubation for 24 hours the colonies were counted. Repeated trials with more dilution were also conducted to avoid swarming bacteria that may cover the plate. However, TVC can be expressed in numbers $\mathrm{ml}^{-1}$.

$\mathrm{TVC}=\mathrm{m} \times 10^{\mathrm{n}} ;$

Here, $\mathrm{m}$ is the number of colonies and $\mathrm{n}$ is the dilution factor.

\section{Statistical analysis}

Mean and standard deviation were followed for statistical analysis. T-test was done and compared with tabulated values for the interpretation of the results. 


\section{Results and Discussion}

\section{Most Probable Number (MPN)}

Most Probable Number (MPN) is a presumptive test in which tube showing gas production are counted. By counting the number of tubes showing a positive result and comparing with standard table, a statistical estimate of the MPN of bacteria were made. Results revealed that samples produced gas bubble to show the positive results of MPN and were significantly varied in their MPN (Table 2). However, the sample 19 secured low MPN index value (Table 4). Average MPN index value for these collected samples was $3.05 \mathrm{ml}^{-1}$ which indicated that the water samples were not potable at all. According to Dubey and Maheshwari (2005), water sample containing gas producing lactose fermenters would not be considered as potable water. The findings of the assessment are in agreement with Alam et al. (2006) who reported that the mean value of Total Coliform

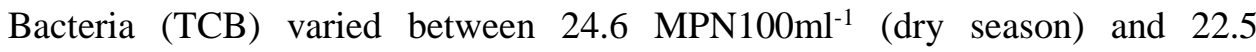
MPN100 $\mathrm{ml}^{-1}$ (monsoon season) in Sylhet City restaurants. These levels are clearly unsafe as far as drinking water is concerned. Thus it might be prudent to monitor the bacteriological quality of drinking water/supply water at the source in addition to resistance profiles of the isolates.

\section{Coliform test (CF)}

In presumptive test, sometimes gas is also produced by non coliform group of bacteria. So, this test is meant for differentiating the coliforms with that of non-coliforms as well as Gram-negative with Gram positive bacteria. In this study, dark centered or nucleated colonies with metallic sheen were noticed which indicate that all the samples were coliform positive (Table 4). The findings of the present study are in agreement with Alam et al. (2005) who reported that the drinking water of each restaurant was contaminated with coliforms in Sylhet city. Health risk score for coliform bacteria was 1,474.77, indicating high risk. Mukhopadhyay et al. (2012) isolated fecal indicator organisms, including Escherichia coli and Enterococcus spp. from 22 $(27.5 \%)$ samples, and reported that the majority (92.5\%) of the water sources were contaminated with coliforms in their studies. Gwimbi (2011) remarked that protected sources of water had significantly less number of colony forming units $(\mathrm{cfu})$ per $100 \mathrm{ml}$ of water sample compared to unprotected sources $(56 \%$ versus $95 \%, \mathrm{p}<0.05)$. These findings suggest that source water protection and good hygiene practices can improve the quality of drinking water where disinfection is not available. 
Table 2. Mean and standard deviation of Most Probable Number (MPN) values of the samples

\begin{tabular}{ccccc}
\hline $\begin{array}{c}\text { Treatment } \\
\text { /Sample Code }\end{array}$ & $\begin{array}{c}\text { MPN } \\
\mathrm{ml}^{-1}(\mathrm{Xi})\end{array}$ & $(\mathrm{Xi}-\overline{\mathrm{X}})$ & $(\mathrm{Xi}-\overline{\mathrm{X}})^{2}$ \\
\hline S1001 & 0.43 & -2.62 & 6.86 \\
S1002 & 0.75 & -2.30 & 5.29 \\
S1003 & 0.43 & -2.62 & 6.86 \\
S1004 & 1.50 & -1.55 & 2.40 \\
S1005 & 24.00 & 20.95 & 438.90 \\
S1006 & 11.00 & 7.95 & 63.20 \\
S1007 & 0.43 & -2.62 & 6.86 \\
S1008 & 0.39 & -2.66 & 7.08 \\
S1009 & 11.00 & 7.95 & 63.20 \\
S1010 & 0.93 & -2.12 & 4.49 \\
S1011 & 0.39 & -2.66 & 7.08 \\
S1012 & 0.43 & -2.62 & 6.86 \\
S1013 & 1.20 & -1.85 & 3.42 \\
S1014 & 0.93 & -2.12 & 4.49 \\
S1015 & 0.34 & -2.71 & 7.34 \\
S1016 & 0.43 & -2.62 & 6.86 \\
S1017 & 4.60 & 1.55 & 2.40 \\
S1018 & 0.93 & -2.12 & 4.49 \\
S1019 & 0.15 & -2.90 & 6.41 \\
S1020 & -2.30 & \\
Total & 0.05 & & \\
Mean & 0.75 & & \\
\hline S1 & 0.74 & \\
\hline
\end{tabular}

\section{Total Viable Count (TVC) or Standard Plate Count (SPC)}

Total Viable Count (TVC) or Standard Plate Count (SPC) was done to enumerate total viable bacteria present in the sample. After inoculation and incubation for 24 hours, the colonies were counted. Results showed that TVC was significantly varied (Table 3). Naturally, the pathogenic bacteria are very much lower in number than the non-pathogenic bacteria. But when there is high concentration of viable bacteria, there is chance of contamination of non-fecal pathogenic 
bacteria. According to guideline of WHO (1996), TVC value should be $1 \times 10^{3}$ cfuml $^{-1}$. The US Environmental Protection Agency (EPA) also recommended that the TVC value should be $500 \mathrm{cfuml}^{-1}$. But, we found much higher TVC value than those values (Table 4). The quality of water used in the popular restaurants of Sylhet City Corporation are at high risk that might be deteriorated during its flow through the water distribution system and also due to probability of non protection of water sources in some cases.

Table 3. Mean and standard deviation from the Total Viable Count (TVC) values of the samples

\begin{tabular}{c|c|c|c}
\hline $\begin{array}{c}\text { Treatment } \\
\text { /Sample Code }\end{array}$ & $\begin{array}{c}\text { Total TVC } \\
\left(\mathrm{cfu} . \mathrm{g}^{-1}\right)(\mathrm{Xi})\end{array}$ & $(\mathrm{Xi}-\overline{\mathrm{X}})$ & $(\mathrm{Xi}-\overline{\mathrm{X}})^{2}$ \\
\hline S1001 & $11.46 \times 10^{6}$ & $-7.44 \times 10^{6}$ & $5.54 \times 10^{13}$ \\
S1002 & $21.94 \times 10^{6}$ & $3.04 \times 10^{6}$ & $9.42 \times 10^{12}$ \\
S1003 & $12.16 \times 10^{6}$ & $-6.74 \times 10^{6}$ & $4.54 \times 10^{13}$ \\
S1004 & $18.80 \times 10^{6}$ & $-1 \times 10^{5}$ & $1 \times 10^{10}$ \\
S1005 & $26.80 \times 10^{6}$ & $7.9 \times 10^{6}$ & $6.24 \times 10^{13}$ \\
S1006 & $24.20 \times 10^{6}$ & $5.3 \times 10^{6}$ & $2.809 \times 10^{13}$ \\
S1007 & $16.40 \times 10^{6}$ & $-2.5 \times 10^{6}$ & $6.25 \times 10^{12}$ \\
S1008 & $19.40 \times 10^{6}$ & $5 \times 10^{5}$ & $2.5 \times 10^{11}$ \\
S1009 & $24.40 \times 10^{6}$ & $5.5 \times 10^{6}$ & $3.025 \times 10^{13}$ \\
S1010 & $19.20 \times 10^{6}$ & $3 \times 10^{5}$ & $9 \times 10^{10}$ \\
S1011 & $18.40 \times 10^{6}$ & $-5 \times 10^{5}$ & $2.5 \times 10^{11}$ \\
S1012 & $18.80 \times 10^{6}$ & $-1 \times 10^{5}$ & $1 \times 10^{10}$ \\
S1013 & $19.60 \times 10^{6}$ & $7 \times 10^{5}$ & $4.9 \times 10^{11}$ \\
S1014 & $24.40 \times 10^{6}$ & $5.5 \times 10^{6}$ & $3.025 \times 10^{13}$ \\
S1015 & $16.20 \times 10^{6}$ & $-2.7 \times 10^{6}$ & $7.29 \times 10^{12}$ \\
S1016 & $13.80 \times 10^{6}$ & $-5.1 \times 10^{6}$ & $2.6 \times 10^{13}$ \\
S1017 & $24.00 \times 10^{6}$ & $5.1 \times 10^{6}$ & $2.6 \times 10^{13}$ \\
S1018 & $16.40 \times 10^{6}$ & $-2.5 \times 10^{6}$ & $6.25 \times 10^{12}$ \\
S1019 & $13.40 \times 10^{6}$ & $-5.5 \times 10^{6}$ & $3.02 \times 10^{13}$ \\
S1020 & $17.80 \times 10^{6}$ & $-1.1 \times 10^{6}$ & $1.21 \times 10^{12}$ \\
\hline Total & $3.78 \times 10^{8}$ & & $3.65 \times 10^{14}$ \\
\hline t-test $(0.05)$ & & $19.30^{* * *}$ & \\
\hline & & & \\
\hline
\end{tabular}


Table 4. Microbial properties of the water samples along with WHO, ISI and US EPA standards

\begin{tabular}{|c|c|c|c|}
\hline Treatment & $\begin{array}{l}\text { Most Probable No. } \\
(\mathrm{MPN}) \mathrm{ml}^{-1}(\mathrm{Xi})\end{array}$ & $\begin{array}{l}\text { Total Viable Count } \\
\left(\text { TVC) }\left(\mathrm{cfu} \mathrm{m} \mathrm{m}^{-1}\right)\right.\end{array}$ & $\begin{array}{l}\text { Coloform } \\
(\# / 100 \mathrm{ml})\end{array}$ \\
\hline S1001 & 0.43 & $11.46 \times 10^{6}$ & $+\mathrm{ve}$ \\
\hline S1002 & 0.75 & $21.94 \times 10^{6}$ & $+v e$ \\
\hline S1003 & 0.43 & $12.16 \times 10^{6}$ & $+\mathrm{ve}$ \\
\hline S1004 & 1.50 & $18.80 \times 10^{6}$ & $+\mathrm{ve}$ \\
\hline S1005 & 24.00 & $26.80 \times 10^{6}$ & +ve \\
\hline S1006 & 11.00 & $24.20 \times 10^{6}$ & $+\mathrm{ve}$ \\
\hline S1007 & 0.43 & $16.40 \times 10^{6}$ & +ve \\
\hline S1008 & 0.39 & $19.40 \times 10^{6}$ & +ve \\
\hline S1009 & 11.00 & $24.40 \times 10^{6}$ & +ve \\
\hline S1010 & 0.93 & $19.20 \times 10^{6}$ & +ve \\
\hline S1011 & 0.39 & $18.40 \times 10^{6}$ & $+\mathrm{ve}$ \\
\hline S1012 & 0.43 & $18.80 \times 10^{6}$ & +ve \\
\hline S1013 & 1.20 & $19.60 \times 10^{6}$ & $+\mathrm{ve}$ \\
\hline S1014 & 0.93 & $24.40 \times 10^{6}$ & +ve \\
\hline S1015 & 0.34 & $16.20 \times 10^{6}$ & +ve \\
\hline S1016 & 0.43 & $13.80 \times 10^{6}$ & $+\mathrm{ve}$ \\
\hline S1017 & 4.60 & $24.00 \times 10^{6}$ & $+\mathrm{ve}$ \\
\hline S1018 & 0.93 & $16.40 \times 10^{6}$ & +ve \\
\hline S1019 & 0.15 & $13.40 \times 10^{6}$ & $+\mathrm{ve}$ \\
\hline S1020 & 0.75 & $17.80 \times 10^{6}$ & +ve \\
\hline $\mathrm{WHO}^{1}$ & MPN positive water & $1 \times 10^{3}$ & -ve \\
\hline $\mathrm{ISI}^{2}$ & $\begin{array}{l}\text { sample in not potable } \\
\text { water (Dubey and }\end{array}$ & & -ve \\
\hline $\mathrm{BD}^{3}$ & Maheshwari, 2005) & & -ve \\
\hline $\mathrm{EPA}^{4}$ & & $500 \mathrm{cfu} / \mathrm{ml}$ & -ve \\
\hline
\end{tabular}

$\mathrm{WHO}^{1}=$ World Health Organization, $\mathrm{ISI}^{2}=$ Indian standard Institute, $\mathrm{BD}^{3}=$ Bangladesh standards and $\mathrm{EPA}^{4}=$ Environmental Protection Agency

\section{Conclusion}

The present investigation on the microbial quality of water used in popular restaurants of Sylhet City Corporation showed that it was highly unsafe for human consumption. Results remarked that these water samples were fecal contaminated and had also great chance of contamination by other pathogenic 
bacteria. Most of the samples were significantly positive to MPN test and TVC values were significantly high. This indicates that other microbes such as fungi, protozoa etc. may be present at alarming concentration in the samples. The risk score for coliform bacteria also indicate high risk as per WHO, ISI and US EPA standards. Thus, it is imperative that the effluent discharge from industries, various domestic and household sources (which enhance levels of heavy metals and pesticides in the city's water supply, especially during the dry season) must be controlled through vigorous efforts. Furthermore, to elucidate the reasons behind the contamination of water, a thorough study of the source water as well as water in the distribution channels must be monitored periodically and treated accordingly. The findings of the study might help the water supply authority as well as the restaurant owners to take necessary steps for the maintenance of microbial quality to prevent waterborne infectious disease both in the urban and rural areas in Bangladesh. However, further studies in depth are urgently needed for time interval.

\section{References}

Ahmed, M. F. and M. M. Rahman. 2000. Water supply and sanitation. ITN-Bangladesh, BUET, Dhaka, Bangladesh. Pp. 331-338.

Alam, R., J. B. Alam, M. M. Hasan, S. R. Das, K. Rahman and B. K. Banik. 2006. Study of water quality of Sylhet City and it's restaurants: health associated risk assessment. Iran. J. Environ. Health Sci. Eng. 3(1): 9-18.

Aziz, K. M. A., B. A. Hoque, S. K. M. Huttly Minnatullah, Z. Hasan, M. K. Patwary, M. M. Rahman and S. Cairncross. 1990. Water supply, sanitation and hygiene education. Report of health impact study in Mirzapur, Bangladesh. Water and Sanitation Series No. 1. The World Bank, Washington DC.

Bain, R., R. Cronk., R. Hossain, S. Bonjour, K. Onda, J. Wright, H. Yang, T. Slaymaker, P. Hunter, A. Prüss-Ustün and J. Bartram. 2014a. Global assessment of exposure to faecal contamination through drinking water based on a systematic review. Trop Med Int Health. 19(8):917-27. doi: 10.1111/tmi.12334.

Bain, R., R. Cronk, J. Wright, H. Yang and J. Bartram. 2014b. Fecal contamination of drinking water in developing countries: a systematic review and meta-analysis. PLoS Medicine 11, e1001644.

Dodoo, D. K., E. K. Quagraine, F. Okai-Sam, J. Kambo Dorsa and J. V. Headley. 2006. Quality analysis of sachet waters in the Cape Coast municipality of Ghana. $J$. Environ. Sci. Health. 41(3): 392-342.

Dubey, R. C. and D. K. Maheshwari. 2005. Practical microbiology. S. Chand \& Company Ltd., New delhi, India.. Pp. 286-299.

Gwimbi, P. 2011. The microbial quality of drinking water in Manonyane community: Maseru District (Lesotho). African Health Sci. 11(3): 474-480.

Howard, K. 2002. Comparison study on river quality. Sci. Total Environ. 207: 141-148. 
Lahlou, Z. M. 2002. Water quality in distribution systems. In National Drinking Water Clearing house fact sheet. West Virginia University. Pp.1-4.

Lim, S. S, T. Vos, A. D. Flaxman, G. Danaei, K. Shibuya, H. Adair-Rohani,......and A. Davis. 2013. A comparative risk assessment of burden of disease and injury attributable to 67 risk factors and risk factor clusters in 21 regions, 1990-2010: a systematic analysis for the Global Burden of Disease Study 2010. The lancet, 380 (9859): 2224-2260.

Mukhopadhyay, C., S. Vishwanath, V. K. Eshwara, S.A. Shankaranarayana and A. Sagir. 2012. Microbial quality of well water from rural and urban households in Karnataka, India: A cross-sectional study. J. Infect. Public Health. 5(3): 257-262.

Nasrin, S., S. K. Saha and M. M. S. Rahman. 2005. Assessment of supply water quality of Khulna City Corporation, Khulna, Bangladesh. Khulna Uni. Studies. 6: 1-2.

Nazz, S. 2008. National encyclopedia of Bangladesh, Asiatic Society of Bangladesh Reported In: Aktar, Z, A. N. M. Fakhruddin, M. S. U. Ahmed, T. Nasreen and S. Parveen. 2009. Assessment and treatment of the supplied pipeline water of selected areas of Dhaka City. Bangladesh J. Scient. Indust. Res. 44(3), 335-340.

Obiri-Danso, K., A. Okore-Hanson and K. Jones. 2003. The microbiological quality of drinking water sold on the streets Kumasi, Ghan. Letters Appl. Microbiol. 37: 334339.

UNCED. 1992. Protection of the quality and supply of freshwater resources: applicaton of integrated approaches to th development, management ans use of water resources. The UN conference on Environment and Development, Chapter 18, Agenda 21.

UNICEF. 2008. UNICEF Handbook on Water Quality. Pp. 20-21, 41, 53-55.

WHO/UNICEF Joint Monitoring Programme for Water Supply and Sanitation. 2000. Global water supply and sanitation assessment 2000 report. Geneva, World Health Organization, Water Supply and Sanitation Collaborative Council and United Nations Children Fund. Pp. 1-87. http://www.unicef.org/wash/files/gafull.pdf.

WHO. 2011. Guidelines for Drinking-Water Quality. $4^{\text {th }}$ edition. WHO, Geneva. Pp.564. Available at http://whqlibdoc.who.int/publications/2011/9789241548151_eng.pdf

WHO. 1996. Guidelines for drinking water quality ( $2^{\text {nd }}$ edn.). World Health Organization, Geneva, Switzerland. 2: 132-167.

Zakia, M. W., M. A. Nizam and M. M. Rahman. 2001. Arsenic and trace element toxicity in ground water for agricultural, drinking and industrial usage. Bangladesh J. Agric. Res. 26(3): 167-177.

Zuthi, M. F. R., M. Biswas and M. N. Bahar. 2009. Assessment of supply water quality in the Chittagong City of Bangladesh. ARPN J. Eng. App. Sci. 4:73-80. Available at:www.arpnjournals.com/jeas/research_papers/rp_2009/jeas_0509_188.pdf 